\title{
Effect of Some Organic and Mineral Salts Supplementation on Hematological, Biochemical, Immunological Constituents and Reproduction in Hassani Goats under Arid Conditions
}

\section{Bahaa Farrag*, Ibrahim Samir Abd El-Hamid, Muhammed Ahmed-Hilmy El-Rayes, Hesham Attia Shedeed, Fawzy Elessawy Younis}

\author{
Animal physiology Department, Animal and Poultry Production Division, Desert Research Centre, Ministry of \\ Agriculture and Land Reclamation, Cairo, Egypt.
}

\begin{abstract}
The aim of this study is to investigate the effect of some mixtures of salt additives containing $(\mathrm{Cu}, \mathrm{Zn}$, $\mathrm{Mg}, \mathrm{Fe}$ and $\mathrm{Co}$ ) in inorganic or organic form on hemato-biochemical blood parameters, immunological status and reproduction in Hassni goats. This study was carried out in the valley of Hederba in Halaieb - Shalateen - Abouramad triangle, south east of Egypt. A total of 36 Hassani goats, body weight $22.48 \pm 0.68 \mathrm{~kg}$, aged 2-4 years were divided into three equal groups ( $\mathrm{n}=12$ in each group). The first group (control) received the basal control diet, the second group (Inorganic-S) were fed on basal diet plus $(2.7 \mathrm{gm} / \mathrm{head} /$ day DM) from salts additive mixtures in inorganic form. The third group (Organic-S) received the same amount of mixture in the organic form. Feeding started one month before breeding season and continued until weaning stage. Hematological, blood biochemical constituents, immunoglobulin (Igs), complement immune proteins and thyroid hormones were measured. Also, does reproductive performance and kid's birth and weaning weights were recorded. Overall mean of serum triiodothyronine $\left(\mathrm{T}_{3}\right)$, thyroxin $\left(\mathrm{T}_{4}\right)$ and cortisol concentrations were significantly $(\mathrm{P}<0.05)$ higher in Organic-S group compared with inorganic or control ones. Overall mean of copper $(\mathrm{Cu})$ and iron $(\mathrm{Fe})$ concentrations were increased $(\mathrm{P}<0.01)$ in treated groups compared with control. Interleukins (2, 6 and 12) decreased in treated groups compared with control. Plasma IgG, IgM and Complement 4 concentrations were significantly $(\mathrm{P}<0.05)$ increased in Organic-S group compared to the other two groups. We concluded that trace-elements supplementation in organic or inorganic forms were beneficial for reproduction, immunology and metabolic performance of Hassani does and growth performance of new born kids under arid conditions.
\end{abstract}

Keywords | Goat, Blood parameters, Immunity, Reproductive performance, Trace elements

\footnotetext{
Received | June 21, 2021; Accepted | July 07, 2021; Published | October 01, 2021

*Correspondence | Bahaa Farrag, Animal physiology Department, Animal and Poultry Production Division, Desert Research Centre, Ministry of Agriculture and Land Reclamation, Cairo, Egypt; Email: drc_bahaa@yahoo.com

Citation | Farrag B, El-Hamid ISA, El-Rayes MAH, Shedeed HA, Younis FE (2021). Effect of some organic and mineral salts supplementation on hematological, biochemical, immunological constituents and reproduction in Hassani goats under arid conditions. Adv. Anim. Vet. Sci. 9(12): 2036-2046. DOI | http://dx.doi.org/10.17582/journal.aavs/2021/9.12.2036.2046

ISSN (Online) | 2307-8316; ISSN (Print) | 2309-3331
}

Copyright $\odot 2021$ Farrag et al. This is an open access article distributed under the Creative Commons Attribution License, which permits unrestricted use, distribution, and reproduction in any medium, provided the original work is properly cited.

\section{INTRODUCTION}

G razing of natural forage provides the least cost source $\mathbf{J}_{\text {of nutrients to ruminant nutrition. In the arid area }}$ of Halaieb, goats and sheep are depending on natural and occasionally salt licks to maintain their mineral requirements. However, there is a considerable variability in the levels of minerals in pasture and mineral mixture
(Badawy, 2005). The pasture in Halaieb-Shalateen-Abou Ramad triangle region contains three main plant species which are poor in their nutritional value, namely Panicum turgidum, Lyicum shawii and Acacia tortilis (E1-Shaer et al., 1997). Rarely, pasture can completely satisfy all mineral requirements of grazing ruminants ( $\mathrm{McD}$ owell et al., 1993). In Halaieb-Shalateen-Abou Ramad triangle region, (Badawy, 2005; Nassar, 2008) found unbalanced plasma 
mineral contents in camels and small ruminants that depend on pastoral areas of Egypt. The balanced mineral supplementation promotes the improvement of livestock production in the arid and semi-arid regions and that maybe correcting mineral deficits in small ruminants which are kept in this region. Pastures often fails to supply all needed mineral elements in adequate quantity throughout the year to grazing ruminants (Underwood and Suttle, 1999). Mineral inadequacies in forages and soils have been reported, to be the principal causes of reproductive failure and low animal productivity (McDowell and Valle, 2000).

Mineral supplementation of sheep is a useful method in reducing the unbalanced salt conditions found in the rangeland of desert regions (like pasture of Halaieb) which affects the production and performance of animals (Badawy et al., 2018).

Trace minerals are needed in adequate quantities for body, are essential nutrients for animal immunity, growth, reproduction and for offspring performance. However, trace elements deficiency among ruminants is common. In addition, neonatal mortalities are associated with trace elements deficiencies (Van Metre and Callan, 2001). Trace minerals are supplemented in the diets of small ruminants in two forms: inorganic and organic salts. But organic minerals have higher retention rate and relative bioavailability than inorganic forms in lambs and kids (Garg et al., 2008; Kumar et al., 2009).

Supplementation of animals with organic minerals enhances their growth and reproductive performances, while it decreases mortality of newborn (Formigoni et al., 2011).

Also, addition of trace elements such as copper $(\mathrm{Cu})$ and cobalt ( $\mathrm{Co}$ ) to diets of animals led to improvement of reproductive performance of dams (Aliarabi et al., 2019) and wool fiber characteristics in newly born (Badawy et al., 2018).

Trace minerals deficiency in the diet alone can reduce animal production by $20-30 \%$. Therefore, supplementation of trace elements in animal diets practiced in order to ensure their rapid growth, enhance reproductive performance and improve immune response (Overton and Yasui, 2014). Deficiencies of trace elements such as cobalt, copper, iron, zinc, and selenium had been reported to occur in all the worldwide climatic zones (Underwood and Suttle, 2001). Micro-minerals imbalances have a great impact on animal's performance causing various problems due to its resistance against other elements within the diet (Tayefi-Nasrabadi et al., 2008). Deficiency of trace minerals can affect the production and performance of sheep and goats (Lengarite et al., 2012). Traditionally, supplemental trace minerals have been supplied to livestock in the form of inorganic salts (sulfates, oxides and chlorides). The use of organic trace minerals is increased due to reports of improved feed efficiency, growth, reproduction and immune response (Swenson, 1998).

Therefore, the present study was carried out to investigate the effect of organic and inorganic mineral supplementation during mating, pregnancy and lactating periods on the reproductive performance and immune status of does and their kids growth performance which grazing in arid rangeland lacking in trace minerals under arid conditions in Egypt.

\section{MATERIALS AND METHODS}

This study was carried out at Ras Hederba Valley, Halaieb and Shalateen Experimental Research Station, Desert Research Center, Ministry of Agriculture, Egypt. The station is located in the Halaieb-Shalateen-Abou Ramad Triangle Region, Red Sea Governorate, about 1300 km south eastern of Cairo with latitude $22,00,720 \mathrm{~N}$ and longitude 36, 48, $955 \mathrm{E}$.

\section{ANIMALS AND MANAGEMENT}

Thirty-six Hassani goats were included in this study. Goats were randomly allotted to three equal experimental groups of 12 does each. Goats aged 2-4 years with an average body weight of $22.48 \pm 0.68 \mathrm{~kg}$, were housed in semi open yards surrounded with a wire fence and roofed with natural grass. Goats grazed on natural pasture about 8 hours daily and received a pelleted concentrate feed mixture $(500 \mathrm{gm} /$ head/day) as basal diets. Fresh water was presented twice daily before and after going to grazing. Goats were healthy and free of any diseases or reproductive disorders. All experimental procedures were conducted in conformity with the EU Directive for the protection of experimental animals (2010/63/EU).

\section{EXPERIMENTAL DESIGN}

Goats were divided into three equal groups. $1^{\text {st }}$ group was kept as control $(n=12)$ and received only the basal diet. The $2^{\text {nd }}$ group (Inorganic-S; $n=12$ ) received the basal diet plus $(2.7 \mathrm{gm} / \mathrm{head} /$ day DM) of salts additive mixtures which contain $(\mathrm{Cu}, \mathrm{Zn}, \mathrm{Mg}$ and $\mathrm{Co})$ in inorganic form. The $3^{\text {rd }}$ group (Organic-S; $n=12$ ) received the basal diet plus (2.7 $\mathrm{gm} / \mathrm{head} /$ day DM) of salts mixtures in organic form (Active Vet Company, USA). Mineral additive in both forms were added with concentrate feed mixture. The experiment was commenced one month before mating and continued until the weaning stage. The chemical composition of the basal or treated diets is presented in (Table 1). Does live body weights were recorded before the starting of treatment and were recorded until kidding. Kid's live birth and weaning weights were recorded using an electronic balance. 
Table 1: Ingredients and chemical composition of concentrate mixture and trace elements of treated diets of Hassani goats.

\begin{tabular}{llll} 
Treatment diets & Composition (\%) & Concentrate mixture & g/kg \\
\hline Ingredient & 25 & Organic matter & 940 \\
\hline Yellow corn & 16.7 & Ash & 60 \\
Cottonseed meal & 30 & Crude protein & 148 \\
\hline Wheat bran & 25 & Ether extract & 55 \\
\hline Sunflower meal & 1 & Neutral detergent fiber & 534 \\
\hline NaCl & 2 & Acid detergent fiber & 369 \\
\hline Limestone & 0.3 & Hemicellulose & 165 \\
\hline Trace minerals & Control & Inorganic form & Organic form \\
\hline Trace elements $(\mathrm{g} / \mathrm{kg} \mathrm{DM})$ & 0.71 & 1.67 & 1.25 \\
\hline Phosphors $(\mathrm{P})$ & 0.63 & 2.00 & 1.35 \\
\hline Zink $(\mathrm{Zn})$ & 0.42 & 1.00 & 1.25 \\
\hline Iron $(\mathrm{Fe})$ & 0.62 & 3.33 & 3.75 \\
\hline Copper $(\mathrm{Cu})$ & 0.41 & 0.66 & 0.63 \\
\hline Selenium $(\mathrm{Se})$ & 0.21 & 0.16 & 0.13 \\
\hline Cobalt $(\mathrm{Co})$ & - & 0.5 & 0.15 \\
\hline Iodine $(\mathrm{I})$ & - & 990.7 & - \\
\hline Caco & - & - & 991.5 \\
\hline Lysine & - & & \\
& & &
\end{tabular}

\section{SYNCHRONIZATION OF ESTRUS}

All does were estrus synchronized using double injunction $\left(1 \mathrm{ml}\right.$ ) of prostaglandin $\mathrm{PGF}_{2 \alpha}$ (Estrumate, $263 \mu \mathrm{g}$ Cloprostenol/ml, Schering-Plough Animal Health, Germany) 11 days apart. Exhibiting estrus was detected using tracer buck that was fitted with dye markers throughout 72 hours. Does that exhibited estrus were naturally mated using mature fertile bucks. Data were recorded during the experimental period for each experimental group.

\section{Blood SAMPLeS}

Blood samples were collected from does during the experimental period (from day zero to 150 days (and directly centrifuged. Serum samples were collected and frozen at $-20^{\circ} \mathrm{C}$ for further analysis.

\section{HeMATOLOGICAL PARAMETERS}

Hemoglobin $(\mathrm{Hb})$ concentration was determined using colorimetric kits (Vitro Scient, Egypt). Packed cell volume percentage (PCV\%) was estimated by the use of the packed cell volume tubes method according to (Cheryl et al., 1992), the number of red blood cells (RBC's, $10^{6} / \mathrm{mm}^{3}$ ) and total count of white blood cells (WBC's, $10^{3} / \mathrm{mm}^{3}$ ) were counted by Thom's hemocytometer slide according to method cited by (Bauer, 1970). The calculations of the erythrocyte indices were done according to (Schalm et al., 1975). Mean corpuscular volume $\left(\mathrm{MCV}, \mu \mathrm{m}^{3}\right)$ was calculated according to equation $\mathrm{MCV}, \mu \mathrm{m}^{3}=\mathrm{PCV}(\%) / \mathrm{RBC}$ 's $\left(10^{6} / \mathrm{mm}^{3}\right) \times 10$.
Mean corpuscular hemoglobin ( $\mathrm{MCH}, \mathrm{pg}$ ) was calculated according to equation $\mathrm{MCH}, \mathrm{pg}=\mathrm{Hb}(\mathrm{g} / \mathrm{dl}) / \mathrm{RBC}$ 's $\left(10^{6}\right.$ $\left./ \mathrm{mm}^{3}\right) \times 10$. Mean corpuscular hemoglobin concentration (MCHC,\%) was calculated according to equation MCHC, $\%=\mathrm{Hb}(\mathrm{g} / \mathrm{dl}) / \mathrm{PCV}(\%) \times 100$

\section{BiocheMiCAL PARAMETERS}

Serum samples from does during the experimental period were subjected to colorimetric analysis using commercial kits for the analysis of urea, creatinine, aspartate amino transferase (AST), alanine aminotransferase (ALT) and $\gamma$-glutamyl transferase (GGT) using commercial kits (Spectrum Biotechnology, Egypt). Calcium (Ca), copper $(\mathrm{Cu})$, selenium $(\mathrm{Se})$ and iron $(\mathrm{Fe})$ were determined using (Inductively Coupled Argon Serum, iCAP 6500 Duo, Thermo Scientific, England). The multi-element certified standard solution (Merch, Germany) was used as a stock solution for instrument standardization.

\section{Serum immunoglobulins (Igs) and complement IMMUNE PROTEINS}

Complement immune proteins including complement 3 (C3) and complement 4 (C4) and serum total immunoglobulin subsets ( $\operatorname{IgG}$ and $\operatorname{IgM}$ ) were measured by ELISA kits according to Abbott Laboratories instructions (Abbott Park, IL 60064 USA).

\section{Hormonal ASSAY}

Triiodothyronine, thyroxine and cortisol hormones were 
analyzed using ELISA kit (Atlas Medical, London). Cortisol hormone was analyzed using ELISA kits (Immunospec Corporation, USA).

\section{STATISTICAL ANALYSiS}

Data of does weights, biochemical, hematological and trace elements metabolic concentrations was analyzed by General Linear Model (GLM) procedure (SAS, 2006) using the following model:

$$
Y i j k=\mu+G i+S j+G^{*} S i j+e i j k
$$

Yijk $=$ observations; $\mu=$ Overall means; $\mathrm{Gi}=$ effect of $i^{\text {th }}$ group (i: $1-3$ ); $S j=$ effect of $j^{\text {th }}$ stages ( $\left.j: 1-3\right) ; G^{*} S i j=$ interaction between groups and stages. eij $\mathrm{k}=$ Experimental error. Duncan's multiple range tests was used to separate means.

Another General Linear Model procedure (SAS, 2006) was used for the statistical analysis of birth and weaning weights for kids using the following model:

$$
Y i j=\mu+T i+e i j
$$

Yij= any observation of $\mathrm{j}^{\text {th }}$ animal within $\mathrm{i}^{\text {th }}$ treatment; $\mu=$ Overall mean; $\mathrm{T} i=$ Effect of $\mathrm{i}^{\text {th }}$ treatment $(\mathrm{i}=1-3)$; eij= Experimental error.

Data expressed as percentages included (estrus detection rate, pregnancy rate and litter size) were analyzed by the chi-squared test.

\section{RESULTS AND DISCUSSION}

\section{REPRODUCTIVE PERFormance OF HASSANi DOES}

Micro minerals play a very important role in the reproduction of farm animals especially, in arid regions that are deficient in their minerals content. Many studies reported that the organic form of mineral supplementation had a positive effect on the reproductive performance of animals.

Reproductive performance included some parameters are presented in Table 2. Our results showed that estrus detection rate was $75.00,83.33$ and $91.67 \%$ of the control, inorganic-S and organic-S groups, respectively, with significant difference $(\mathrm{P}<0.05)$ among the three groups.

Pregnancy rate increased $(\mathrm{P}<0.05)$ in organic-S group (91.67\%) followed by inorganic-S (75.00\%) compared with control $(66.67 \%)$. Litter size increased $(\mathrm{P}<0.05)$ in organic-S (172.7\%) followed by the control group (162.5\%) then inorganic-S (155.6). Organic-S group had higher $(\mathrm{P}<0.05)$ twins' rate $(72.73 \%)$ than those of control or inorganic-S groups (52.60 and 66.67\%), respectively. While, no significant difference was detected in single rate of the experimental groups. It is well known that trace elements play important roles for fertility during the breeding season (Kumar, 2003).

Our results, concerning the improvement of goat's reproduction, were in agreement with studies in other species. Senosy et al. (2018) demonstrated that reproductive performance including ovulation and pregnancy rates were significantly improved as a result of organic bound phosphorous injection twice a week for successive three weeks in Farafra ewes. Ahola et al. (2004) found that cows receiving trace minerals $(\mathrm{Zn}, \mathrm{Cu}$ and $\mathrm{Mn})$ had higher pregnancy rates than non-supplemented. Contrary to the current research, Boland et al. (2005) did not report any effect of selenium supplement on reproductive parameters in sheep.

Table 2: Reproductive performance of Hassani does fed a control diet or a diet supplemented with trace-elements in inorganic or organic forms under arid conditions.

\begin{tabular}{lllll}
\hline Item & Control & Inorganic-S & Organic-S & P \\
\hline Estrus detection rate \% & $75.00^{\mathrm{C}}(9 / 12)$ & $83.33^{\mathrm{B}}(10 / 12)$ & $91.67^{\mathrm{A}}(11 / 12)$ & 0.05 \\
\hline Pregnancy rate \% & $66.67^{\mathrm{C}}(8 / 12)$ & $75.00^{\mathrm{B}}(9 / 12)$ & $91.67^{\mathrm{A}}(11 / 12)$ & 0.05 \\
\hline litter size \% & $162.5^{\mathrm{B}}(13 / 8)$ & $155.6^{\mathrm{C}}(14 / 9)$ & $172.7^{\mathrm{A}}(19 / 11)$ & 0.05 \\
\hline Single rate \% & $37.50(3 / 8)$ & $33.33(3 / 9)$ & $27.27(3 / 11)$ & 0.89 \\
Twins rate \% & $62.50^{\mathrm{B}}(5 / 8)$ & $66.67^{\mathrm{B}}(6 / 9)$ & $72.73^{\mathrm{A}}(8 / 11)$ & 0.05
\end{tabular}

${ }^{A-B}$ letters among groups differ significantly $(\mathrm{P}<0.05)$.

Table 3: Birth and weaning weights $(\mathrm{Kg})$ of newly born kids born from does fed a basic diet or supplemented with trace

\begin{tabular}{|c|c|c|c|c|}
\hline Traits & Control & Inorganic-S & Organic-S & $\mathbf{P}$ \\
\hline Birth weight $(\mathrm{kg})$ & $1.44^{\mathrm{B}} \pm 0.07$ & $1.70^{A_{ \pm}} 0.07$ & $1.80^{A_{ \pm}} 0.06$ & \multirow[t]{2}{*}{0.05} \\
\hline Weaning weight $(\mathrm{Kg})$ & $5.20^{\mathrm{B}} \pm 0.24$ & $6.22^{\mathrm{A}} \pm 0.23$ & $6.25^{\mathrm{A}} \pm 0.20$ & \\
\hline
\end{tabular}
elements in inorganic or organic forms $(\mathrm{LSM} \pm \mathrm{SE})$. 


\section{KIDS WEIGHTS}

Organic and inorganic minerals supplementation for does had a positive significant effect on the birth and weaning weights of their kids (Table 3). Kids born from goats supplemented with organic-S and inorganic-S showed higher birth weight than kids born by control goats $(1.80 \pm$ $0.06,1.70 \pm 0.07$ and $1.44 \pm 0.07 \mathrm{~kg}$, respectively, $\mathrm{P}=0.05)$. In the same context, weaning weight of kids born from goats supplemented with organic-S and inorganic-S showed higher weaning weight than kids born by control goats $(6.25 \pm 0.20,6.22 \pm 0.23$ and $5.20 \pm 0.24 \mathrm{~kg}$, respectively, $\mathrm{P}=0.05)$. The present findings were agreed with Sallam et al. (2017) who found that significant difference in birth and weaning weights among kids whose dams were treated with organic minerals mixture supplementation compared with untreated Egyptian goat. Aliarabi et al. (2019) found that body weight at birth and weaning were significantly higher $(\mathrm{P}<0.01)$ in Mehraban lambs whose mothers were given bolus containing $\mathrm{Zn}, \mathrm{Co}$, and Se compared to ewes in control group. A few studies reported the effect of trace minerals supplementation on birth and weaning weight by administration of these trace minerals in small ruminants. Norouzian et al. (2014) reported that birth weight did not differ due to Cobalt supplementation in late pregnancy of ewes which is in disagreement with our results.

\section{Changes IN SERUM Mineral CONCENTRations} DURING PREGNANCY STAGES

Changes of some serum trace elements in Hassani does fed a basic diet or a diet supplemented with organic or inorganic salts during different pregnancy stages are shown in Table 4. The results indicated that the plasma $\mathrm{Cu}$, Se and Fe concentrations of serum does differs $(\mathrm{P}<0.05)$ among groups. Plasma $\mathrm{Ca}$ concentration mean did not differ $(\mathrm{P}>$ $0.05)$ among groups. The serum $\mathrm{Cu}$ concentration of does were significantly higher in treated groups $(20.58 \pm 1.30$ and $23.46 \pm 1.30 \mathrm{mg} / \mathrm{dL}$ ) respectively, than control group $(10.91 \pm 1.30 \mathrm{mg} / \mathrm{dL})$. In the same context, there were significant effects of stages of pregnancy between groups with respect to copper and selenium concentrations. These results were in agreement with the finding of another study in which supplementary administration of Se to ewes on $\mathrm{Cu}$ deficient pastures increased $\mathrm{Cu}$ status (Cristaldi et al., 2005). The present results showed that inorganic-S group achieved the highest overall mean values of serum Se $(1.21 \pm 0.01 \mathrm{mg} / \mathrm{dL})$ while, organic-S group achieved the highest overall mean values of serum Fe $(47.24 \pm 0.01$ $\mathrm{mg} / \mathrm{dL}$ ) and highest overall mean values of serum $\mathrm{Cu}$ $(23.46 \pm 1.30 \mathrm{mg} / \mathrm{dL})$. Our current results are consistent with previous reports in different animal species such as sheep (Senosy et al., 2018; Abdelrahman et al., 2017), goats (Pechova et al., 2009) and dairy cows (Kinal et al., 2007).

Table 4: Changes of some serum trace-elements in Hassani does fed a basic diet or a diet supplemented with organic or inorganic salts during different pregnancy stages under arid conditions.

\begin{tabular}{|c|c|c|c|c|c|c|c|c|c|c|}
\hline \multirow[t]{2}{*}{ Items } & \multirow[t]{2}{*}{ Groups } & \multicolumn{6}{|c|}{ Pregnancy stages } & \multicolumn{3}{|l|}{$\mathbf{P}$} \\
\hline & & $\begin{array}{l}\text { Early-stage } \\
\text { (18-30 d) }\end{array}$ & $\begin{array}{l}\text { Mid-stage } \\
\text { (60-90 d) }\end{array}$ & $\begin{array}{l}\text { Late-stage } \\
\text { (120-150 d) }\end{array}$ & $\pm \mathrm{SE}$ & Overall & $\pm \mathrm{SE}$ & G & $\mathrm{S}$ & $\mathrm{G} \times \mathrm{S}$ \\
\hline \multirow[t]{4}{*}{$\mathrm{Ca}(\mathrm{mg} / \mathrm{dL})$} & Control & 21.36 & 22.00 & 22.55 & \multirow[t]{3}{*}{1.02} & 21.97 & \multirow[t]{3}{*}{0.59} & \multirow[t]{3}{*}{0.21} & \multirow[t]{3}{*}{0.72} & \multirow[t]{3}{*}{0.42} \\
\hline & In-organic-S & 22.34 & 22.59 & 19.95 & & 21.63 & & & & \\
\hline & Organic-S & 20.56 & 20.44 & 20.51 & & 20.50 & & & & \\
\hline & Overall & 21.42 & 21.68 & 21.00 & 0.59 & & & & & \\
\hline \multirow[t]{4}{*}{$\mathrm{Cu}(\mathrm{mg} / \mathrm{dL})$} & Control & 6.86 & 13.79 & 12.08 & \multirow[t]{3}{*}{2.26} & $10.91^{\mathrm{B}}$ & \multirow[t]{3}{*}{1.30} & \multirow[t]{3}{*}{0.05} & \multirow[t]{3}{*}{0.01} & \multirow[t]{3}{*}{0.95} \\
\hline & In-organic-S & 16.42 & 22.42 & 22.89 & & $20.58^{\mathrm{A}}$ & & & & \\
\hline & Organic-S & 18.15 & 25.78 & 26.46 & & $23.46^{\mathrm{A}}$ & & & & \\
\hline & Overall & $13.81^{\mathrm{Y}}$ & $20.66^{\mathrm{x}}$ & $20.48^{\mathrm{X}}$ & 1.30 & & & & & \\
\hline \multirow{3}{*}{$\begin{array}{l}\mathrm{Se} \\
(\mathrm{mg} / \mathrm{dL})\end{array}$} & Control & 1.14 & 1.16 & 1.19 & \multirow[t]{3}{*}{0.03} & $1.16^{\mathrm{AB}}$ & \multirow[t]{3}{*}{0.01} & \multirow[t]{3}{*}{0.05} & \multirow[t]{3}{*}{0.01} & \multirow[t]{3}{*}{0.18} \\
\hline & In-organic-S & 1.18 & 1.17 & 1.28 & & $1.21^{\mathrm{A}}$ & & & & \\
\hline & Organic-S & 1.03 & 1.16 & 1.23 & & $1.14^{\mathrm{B}}$ & & & & \\
\hline \multirow{5}{*}{$\begin{array}{l}\mathrm{Fe} \\
(\mathrm{mg} / \mathrm{dL})\end{array}$} & Overall & $1.11^{\mathrm{Y}}$ & $1.16^{\mathrm{Y}}$ & $1.23^{x}$ & 0.01 & & & & & \\
\hline & Control & 20.64 & 21.13 & 21.69 & \multirow[t]{3}{*}{104.43} & $21.16^{\mathrm{B}}$ & \multirow[t]{3}{*}{0.01} & \multirow[t]{3}{*}{0.05} & \multirow[t]{3}{*}{0.50} & \multirow[t]{3}{*}{0.63} \\
\hline & In-organic-S & 38.19 & 47.00 & 36.99 & & $40.73^{\mathrm{A}}$ & & & & \\
\hline & Organic-S & 43.41 & 47.71 & 50.63 & & $47.24^{\mathrm{A}}$ & & & & \\
\hline & Overall & 34.08 & 38.61 & 36.44 & 8.67 & & & & & \\
\hline
\end{tabular}


Table 5: Changes of kidney and liver functions in Hassani does fed a basic diet or a diet supplemented with inorganic or organic salts during different pregnancy stages under arid conditions.

\begin{tabular}{|c|c|c|c|c|c|c|c|c|c|c|}
\hline \multirow[t]{2}{*}{ Items } & \multirow[t]{2}{*}{ Groups } & \multicolumn{4}{|c|}{ Pregnancy stages } & \multicolumn{5}{|c|}{$\mathbf{P}$} \\
\hline & & $\begin{array}{l}\text { Early-stage } \\
(18-30 \mathrm{~d})\end{array}$ & $\begin{array}{l}\text { Mid-stage } \\
(60-90 \mathrm{~d})\end{array}$ & $\begin{array}{l}\text { Late-stage } \\
(120-150 \mathrm{~d})\end{array}$ & $\pm \mathrm{SE}$ & Overall & $\pm \mathrm{SE}$ & G & $S$ & $\mathrm{G} \times \mathrm{S}$ \\
\hline \multirow{4}{*}{$\begin{array}{l}\text { Urea } \\
(\mathrm{g} / \mathrm{dL})\end{array}$} & Control & 57.07 & 43.57 & 51.56 & \multirow[t]{3}{*}{4.33} & 50.73 & \multirow[t]{3}{*}{2.50} & \multirow[t]{3}{*}{0.35} & \multirow[t]{3}{*}{0.30} & \multirow[t]{3}{*}{0.12} \\
\hline & In-organic-S & 55.45 & 62.12 & 50.15 & & 55.90 & & & & \\
\hline & Organic-S & 56.35 & 47.57 & 53.69 & & 52.93 & & & & \\
\hline & Overall & 56.28 & 51.08 & 51.80 & 2.50 & & & & & \\
\hline \multirow{3}{*}{$\begin{array}{l}\text { Crea } \\
(\mathrm{g} / \mathrm{dL})\end{array}$} & Control & $2.09^{\mathrm{bc}}$ & $2.10^{\mathrm{bc}}$ & $1.55^{\mathrm{d}}$ & \multirow[t]{3}{*}{0.09} & 1.91 & \multirow[t]{3}{*}{0.05} & \multirow[t]{3}{*}{0.16} & \multirow[t]{3}{*}{0.01} & \multirow[t]{3}{*}{0.01} \\
\hline & In-organic-S & $2.08^{\mathrm{bc}}$ & $1.89^{c}$ & $2.24^{\mathrm{ab}}$ & & 2.07 & & & & \\
\hline & Organic-S & $1.72^{c}$ & $2.48^{\mathrm{a}}$ & $1.74^{c}$ & & 1.98 & & & & \\
\hline \multirow{4}{*}{$\begin{array}{l}\mathrm{AST} \\
\text { (IU/L) }\end{array}$} & Overall & $1.96^{\mathrm{Y}}$ & $2.16^{\mathrm{X}}$ & $1.84^{\mathrm{Y}}$ & 0.05 & & & & & \\
\hline & Control & $53.46^{\mathrm{c}}$ & $68.99 b^{c}$ & $99.18^{a}$ & \multirow[t]{3}{*}{6.48} & $73.87^{\mathrm{A}}$ & \multirow[t]{3}{*}{3.74} & \multirow[t]{3}{*}{0.05} & \multirow[t]{3}{*}{0.01} & \multirow[t]{3}{*}{0.01} \\
\hline & In-organic-S & $61.25^{\mathrm{bc}}$ & $54.10^{c}$ & $60.50^{\mathrm{bc}}$ & & $58.61^{\mathrm{B}}$ & & & & \\
\hline & Organic-S & $63.93^{b c}$ & $65.60^{\mathrm{bc}}$ & $81.03^{\mathrm{ab}}$ & & $70.18^{\mathrm{A}}$ & & & & \\
\hline \multirow{4}{*}{$\begin{array}{l}\text { ALT } \\
(\mathrm{IU} / \mathrm{L})\end{array}$} & Overall & $59.54^{Y}$ & $62.60^{Y}$ & $80.28^{\mathrm{X}}$ & 3.74 & & & & & \\
\hline & Control & 84.36 & 79.22 & 77.25 & \multirow[t]{3}{*}{4.35} & 80.27 & \multirow[t]{3}{*}{2.51} & \multirow[t]{3}{*}{0.57} & \multirow[t]{3}{*}{0.68} & \multirow[t]{3}{*}{0.49} \\
\hline & In-organic-S & 79.18 & 79.64 & 81.90 & & 80.24 & & & & \\
\hline & Organic-S & 75.18 & 82.58 & 73.10 & & 67.95 & & & & \\
\hline \multirow{5}{*}{$\begin{array}{l}\text { GGT } \\
\text { (IU/L) }\end{array}$} & Overall & 79.57 & 80.48 & 77.41 & 2.51 & & & & & \\
\hline & Control & 58.66 & 40.14 & 58.03 & \multirow[t]{3}{*}{7.47} & $52.27^{\mathrm{A}}$ & \multirow[t]{4}{*}{4.31} & \multirow[t]{4}{*}{0.05} & \multirow[t]{4}{*}{0.62} & 0.13 \\
\hline & In-organic-S & 46.19 & 40.42 & 56.27 & & $47.62^{\mathrm{AB}}$ & & & & \\
\hline & Organic-S & 33.20 & 48.38 & 32.71 & & $38.09^{\mathrm{B}}$ & & & & \\
\hline & Overall & 46.01 & 42.98 & 49.00 & 4.31 & & & & & \\
\hline
\end{tabular}

These findings are in agreement with (Abd El-Hamid et al., 2019) who found that inorganic-S and organic-S groups had the higher values of $\mathrm{Cu}, \mathrm{P}$ and $\mathrm{Fe}$ compared with control one in sheep. Trace mineral deficiency during fertilization and conception stages lead to increase some risks including anaemia, pregnancy induced hypertension, fetal growth restriction and increase maternal and fetal mortality (Cheesbrough, 2010). In this study, the overall positive effects of the organic and inorganic mineral supplementations on the blood $\mathrm{Cu}, \mathrm{Fe}$ and $\mathrm{Se}$, compared with the control group, could be attributed to the more absorption of these minerals from the gastrointestinal tract into the blood compared with the diet free of the supplemental minerals (Suttle, 2010).

\section{KIDNEY AND LIVER FUNCTIONS}

During the different pregnancy stages, changes of kidney and liver functions in Hassani does fed a basic diet or a diet supplemented with organic or inorganic salts are shown in Table 5 . The obtained results are demonstrated that treated groups have numerically higher of serum urea and creatinine concentrations than this for control group. However, the stage of pregnancy or the interaction between treatment and pregnancy stage has significant effects on serum creatinine concentration. Our current results are in agreement of Abdelrahman et al. (2017); Antunovic et al. (2011) who reported that the values of urea-N and creatinine were fell within the reference range. El-Rayes (2019) also stated that inorganic mineral additive resulted in the highest blood urea followed by that of ewes received organic mineral additive and the least is the control group. High blood urea could be due to increase cortisone level affecting the catabolism of protein in the body Silanikove (2000). Creatinine did not affected by treatment, since high creatinine is indicative of poor protein and amino acid metabolism that can lead to impaired renal function and cardiac infarction.

In Table 5, levels of AST, ALT and GGT (IU/L) were higher in control group $(73.87 \pm 3.74,80.27 \pm 2.51$ and $52.27 \pm 4.31 \mathrm{IU} / \mathrm{L})$, respectively compared to organic-S group $(58.61 \pm 3.74,80.24 \pm 2.51$ and $47.62 \pm 4.31$, respectively. Inorganic-S group $(70.18 \pm 3.74,67.95 \pm 2.51$ and $38.09 \pm 4.31$, respectively. AST and GGT increased with advancing pregnancy. Growth of fetus needs more efforts from liver for amino acids incorporation in different tis- 
sues. Increased fetal growth needs utilization of amino acids from the maternal serum protein Antunovic et al. (2002). From these results, this may be indicated that trace elements supplementation did not affect the liver function where AST and ALT values were within the normal levels.

\section{BLOOD CYTOKINE}

Changes in some plasma immune-cell-mediators (cytokine) were presented in Table 6. Organic-S group increased $(\mathrm{P}<0.05)$ tumor necrosis factor $(\mathrm{TNF})$ and Interleukin1(IL-1). Meanwhile, control group led to significant increase in IL-2, IL-6 and IL-12. IL-2, IL-6 and IL-12 values decreased by adding organic and inorganic mineral. The decrease was more pronounced by inorganic mineral. It well established that reactive oxygen species exert a biphasic effect during pregnancy and parturition at adequate levels are fundamental for many physiological pathways to occur such as embryo implantation (Mutinati et al., 2013). Accordingly, the reduction in IL-2, IL-6 and IL-12 values by mineral additives might be of beneficial effect for goats to complete pregnancy and kids delivery.

\section{Hematological parameters}

Data for haematological parameters in Hassani goats fed a basic diet or a diet supplemented with organic or inorganic salts are shown in Table 7. Overall means of blood $\mathrm{Hb}$ concentration (g/dl), PCV and MCHC (\%), RBCs (106/ $\mathrm{mm} 3)$ and $\mathrm{MCV}(\mu \mathrm{m} 3)$ in treated groups were significantly different from the control. Numerical increment in overall means of WBCs $(103 / \mathrm{mm} 3)$ were found in control group $(8.53 \pm 1.01106 / \mathrm{mm} 3)$ compared with In-organic-S group $(6.78 \pm 1.01106 / \mathrm{mm} 3)$ and organic-S group $(5.50 \pm 1.01106 /$ $\mathrm{mm} 3$ ) with no significant difference. However, the difference due to treatment, stages of pregnancy and the interaction between them did not show any significance. Red and white blood cells were higher in control group compared to treated groups. $\mathrm{RBCs}, \mathrm{WBC}$ and haemoglobin concentration $(\mathrm{Hb})$ as well as mean corpuscular haemoglobin concentration (MCHC) decreased in treated organic-S and in-organic-S groups than control ones (Table 5). The decrease was more pronounced in ewes received inorganic-S additive. These results are completely consistent with El-Rayes (2019) who reported the same trend on sheep. Contrary to our results, ElRayes (2019) who stated that addition of organic minerals additive to pregnant ewes resulted in significant increase in WBCs count which enhance immune capacity of ewes, but this may be due to the difference in animal type. Cook et al. (2002) stated that long-standing exposure to heat stress is responsible for altering number and reactivity of immune cells and immunoglobulin production. The present results might indicate that inorganic mineral additive augmented the stress of haemodilution.

Table 6: Changes in some blood cytokine in Hassani does fed a basic diet or a diet supplemented with inorganic or organic salts during different pregnancy stages under arid conditions.

\begin{tabular}{|c|c|c|c|c|c|c|c|c|c|c|}
\hline \multirow[t]{2}{*}{ Items } & \multirow[t]{2}{*}{ Groups } & \multicolumn{6}{|c|}{ Pregnancy stages } & \multicolumn{3}{|l|}{$\mathbf{P}$} \\
\hline & & $\begin{array}{l}\text { Early-stage } \\
(18-30 \mathrm{~d})\end{array}$ & $\begin{array}{l}\text { Mid-stage } \\
(60-90 \mathrm{~d})\end{array}$ & $\begin{array}{l}\text { Late-stage } \\
(120-150 \text { d) }\end{array}$ & $\pm \mathrm{SE}$ & Overall & $\pm \mathrm{SE}$ & $\mathrm{G}$ & $\mathrm{S}$ & $\mathrm{G} \times \mathrm{S}$ \\
\hline \multirow{4}{*}{$\begin{array}{l}\text { TNF } \\
(\mathrm{pg} / \mathrm{ml})\end{array}$} & Control & $13.83^{\text {cd }}$ & $16.27^{c}$ & $14.73^{c}$ & \multirow[t]{3}{*}{2.01} & $14.94^{\mathrm{B}}$ & \multirow[t]{3}{*}{1.16} & \multirow[t]{3}{*}{0.01} & \multirow[t]{3}{*}{0.13} & \multirow[t]{3}{*}{0.01} \\
\hline & In-organic-S & $18.50^{\mathrm{bc}}$ & $8.27^{\mathrm{d}}$ & $7.97^{\mathrm{d}}$ & & $11.57^{\mathrm{B}}$ & & & & \\
\hline & Organic-S & $25.77^{a}$ & $24.23^{\mathrm{ab}}$ & $26.83^{a}$ & & $25.16^{\mathrm{A}}$ & & & & \\
\hline & Overall & 19.36 & 16.25 & 16.51 & 1.16 & & & & & \\
\hline \multirow{3}{*}{$\begin{array}{l}\text { IL-1 } \\
(\mathrm{pg} / \mathrm{ml})\end{array}$} & Control & 30.40 & 29.40 & 20.20 & \multirow[t]{3}{*}{5.71} & $26.66^{\mathrm{A}}$ & \multirow[t]{3}{*}{3.29} & \multirow[t]{3}{*}{0.01} & \multirow[t]{3}{*}{0.80} & \multirow[t]{3}{*}{0.67} \\
\hline & In-organic-S & 12.03 & 9.50 & 8.87 & & $10.13^{\mathrm{B}}$ & & & & \\
\hline & Organic-S & 20.57 & 25.70 & 26.83 & & $24.36^{\mathrm{A}}$ & & & & \\
\hline \multirow{4}{*}{$\begin{array}{l}\text { IL-2 (pg/ } \\
\mathrm{ml})\end{array}$} & Overall & 21.00 & 21.53 & 18.63 & \multirow{4}{*}{$\begin{array}{l}3.29 \\
3.05\end{array}$} & & & & & \\
\hline & Control & 36.53 & 33.13 & 32.67 & & $34.11^{\mathrm{A}}$ & \multirow{3}{*}{1.67} & \multirow[t]{3}{*}{0.01} & \multirow[t]{3}{*}{0.92} & \multirow[t]{3}{*}{0.87} \\
\hline & In-organic-S & 22.33 & 21.93 & 23.87 & & $22.71^{\mathrm{B}}$ & & & & \\
\hline & Organic-S & 24.23 & 25.27 & 25.90 & & $25.13^{\mathrm{B}}$ & & & & \\
\hline \multirow{4}{*}{$\begin{array}{l}\text { IL-6 } \\
\text { (pg/ml) }\end{array}$} & Overall & 27.70 & 26.77 & 27.47 & 0.92 & & & & & \\
\hline & Control & 28.70 & 28.10 & 45.30 & \multirow{3}{*}{3.32} & $34.03^{\mathrm{A}}$ & \multirow{3}{*}{1.91} & \multirow{3}{*}{0.01} & \multirow{3}{*}{0.01} & \multirow{3}{*}{0.82} \\
\hline & In-organic-S & 18.00 & 20.37 & 30.00 & & $22.78^{\mathrm{B}}$ & & & & \\
\hline & Organic-S & 21.43 & 23.67 & 38.07 & & $27.72^{\mathrm{B}}$ & & & & \\
\hline \multirow{5}{*}{$\begin{array}{l}\text { IL-12 } \\
(\mathrm{pg} / \mathrm{ml})\end{array}$} & Overall & $22.71^{\mathrm{X}}$ & $24.04^{\mathrm{X}}$ & $37.78^{\mathrm{Y}}$ & 1.91 & & & & & \\
\hline & Control & 23.47 & 25.00 & 25.83 & \multirow[t]{3}{*}{1.87} & $24.67^{\mathrm{A}}$ & \multirow[t]{4}{*}{1.07} & \multirow[t]{4}{*}{0.01} & \multirow[t]{4}{*}{0.27} & 0.77 \\
\hline & In-organic-S & 15.70 & 14.80 & 15.97 & & $15.84^{\mathrm{B}}$ & & & & \\
\hline & Organic-S & 22.63 & 25.20 & 27.57 & & $15.13^{\mathrm{B}}$ & & & & \\
\hline & Overall & 20.60 & 21.66 & 23.12 & 1.07 & & & & & \\
\hline
\end{tabular}


Table 7: Changes of some hematological parameters in Hassani does fed a basic diet or a diet supplemented with inorganic or organic salts during different pregnancy stages under arid conditions

\begin{tabular}{|c|c|c|c|c|c|c|c|c|c|c|}
\hline \multirow[t]{2}{*}{ Items } & \multirow[t]{2}{*}{ Groups } & \multicolumn{6}{|c|}{ Pregnancy stages } & \multicolumn{3}{|c|}{ Pvalue } \\
\hline & & $\begin{array}{l}\text { Early-stage } \\
18-30 \mathrm{~d}\end{array}$ & $\begin{array}{l}\text { Mid-stage } \\
60-90 \mathrm{~d}\end{array}$ & $\begin{array}{l}\text { Late-stage } \\
120-150 \mathrm{~d}\end{array}$ & $\pm \mathrm{SE}$ & Overall & $\pm \mathrm{SE}$ & $\mathrm{G}$ & S & $\mathrm{G} \times \mathrm{S}$ \\
\hline \multirow[t]{4}{*}{$\mathrm{Hb}(\mathrm{g} / \mathrm{dl})$} & Control & 19.40 & 18.13 & 20.30 & \multirow[t]{3}{*}{0.78} & $19.27^{\mathrm{A}}$ & \multirow[t]{3}{*}{0.45} & \multirow[t]{3}{*}{0.01} & \multirow[t]{3}{*}{0.11} & \multirow[t]{3}{*}{0.46} \\
\hline & In-organic-S & 16.93 & 14.53 & 16.13 & & $15.86^{\mathrm{B}}$ & & & & \\
\hline & Organic-S & 16.57 & 16.73 & 16.87 & & $16.72^{\mathrm{B}}$ & & & & \\
\hline & Overall & 17.63 & 16.64 & 17.76 & 0.45 & & & & & \\
\hline \multirow[t]{4}{*}{ PCV (\%) } & Control & 19.33 & 20.83 & 20.77 & \multirow[t]{3}{*}{1.48} & $20.31^{\mathrm{C}}$ & \multirow[t]{3}{*}{0.85} & \multirow[t]{3}{*}{0.01} & \multirow[t]{3}{*}{0.19} & \multirow[t]{3}{*}{0.73} \\
\hline & In-organic-S & 25.07 & 29.33 & 28.73 & & $27.71^{\mathrm{A}}$ & & & & \\
\hline & Organic-S & 23.57 & 24.03 & 24.10 & & $23.90^{\mathrm{B}}$ & & & & \\
\hline & Overall & 22.65 & 24.73 & 24.53 & 0.85 & & & & & \\
\hline \multirow{4}{*}{$\begin{array}{l}\mathrm{RBCs}\left(10^{6} /\right. \\
\left.\mathrm{mm}^{3}\right)\end{array}$} & Control & 13.71 & 14.17 & 13.65 & \multirow[t]{3}{*}{0.74} & $13.84^{\mathrm{A}}$ & \multirow[t]{3}{*}{0.42} & \multirow[t]{3}{*}{0.01} & \multirow[t]{3}{*}{0.66} & \multirow[t]{3}{*}{0.43} \\
\hline & In-organic-S & 10.13 & 10.65 & 9.97 & & $10.24^{\mathrm{C}}$ & & & & \\
\hline & Organic-S & 13.07 & 11.00 & 11.64 & & $11.90^{\mathrm{B}}$ & & & & \\
\hline & Overall & 12.30 & 11.94 & 11.75 & 0.42 & & & & & \\
\hline \multirow{4}{*}{$\begin{array}{l}\text { WBCs }\left(10^{3} /\right. \\
\left.\mathrm{mm}^{3}\right)\end{array}$} & Control & 8.70 & 7.26 & 9.94 & \multirow[t]{3}{*}{1.75} & 8.53 & \multirow[t]{3}{*}{1.01} & \multirow[t]{3}{*}{0.12} & \multirow[t]{3}{*}{0.82} & \multirow[t]{3}{*}{0.83} \\
\hline & In-organic-S & 6.21 & 6.69 & 6.78 & & 6.56 & & & & \\
\hline & Organic-S & 4.37 & 6.63 & 5.23 & & 5.50 & & & & \\
\hline & Overall & 6.42 & 6.86 & 7.31 & 1.01 & & & & & \\
\hline \multirow[t]{4}{*}{$\mathrm{MCH}(\mathrm{pg})$} & Control & 14.18 & 12.85 & 15.05 & 0.89 & 14.02 & 0.51 & 0.08 & 0.24 & 0.07 \\
\hline & In-organic-S & 16.75 & 13.85 & 16.23 & & 15.61 & & & & \\
\hline & Organic-S & 12.73 & 15.30 & 14.57 & & 14.20 & & & & \\
\hline & Overall & 14.55 & 14.00 & 15.28 & 0.51 & & & & & \\
\hline $\mathrm{MCHC}(\%)$ & Control & 103.34 & 87.30 & 98.71 & 7.09 & $96.44^{\mathrm{A}}$ & 4.09 & 0.01 & 0.16 & 0.69 \\
\hline & In-organic-S & 68.04 & 49.63 & 55.98 & & $57.88^{\mathrm{C}}$ & & & & \\
\hline & Organic-S & 70.65 & 70.45 & 70.54 & & $70.54^{\mathrm{B}}$ & & & & \\
\hline & Overall & 80.67 & 69.12 & 75.07 & 4.09 & & & & & \\
\hline $\operatorname{MCV}\left(\mu \mathrm{m}^{3}\right)$ & Control & 14.23 & 14.82 & 15.45 & 1.88 & $14.80^{\mathrm{C}}$ & 1.08 & 0.01 & 0.18 & 0.84 \\
\hline & In-organic-S & 24.87 & 27.79 & 29.31 & & $27.32^{\mathrm{A}}$ & & & & \\
\hline & Organic-S & 18.16 & 21.87 & 20.72 & & $20.24^{\mathrm{B}}$ & & & & \\
\hline & Overall & 19.09 & 21.46 & 21.82 & 1.08 & & & & & \\
\hline
\end{tabular}

$\mathrm{A}-\mathrm{B}$ values with different superscript letters in the same column are statistically different $(\mathrm{P}<0.01)$. $\mathrm{G}=$ groups, $\mathrm{S}=$ pregnancy stages.

Plasma thyroid AND CORTISOL HORMONES CONCENTRATIONS

$\mathrm{T}_{3}, \mathrm{~T}_{4}$ and cortisol concentrations in Hassani does are illustrated in Figure 1. The differences in overall means plasma $\mathrm{T}_{3}\left(\mathrm{~T}_{3}, \mathrm{ng} / \mathrm{mL}\right)$ concentrations between organic-S and control or inorganic groups $(0.79 \pm 0.09$ vs. $0.46 \pm 0.09$ and $0.47 \pm 0.09 \mathrm{ng} / \mathrm{ml}$, respectively) were significant differences $(\mathrm{P}<0.05)$. The same trend was observed in plasma $\mathrm{T}_{4}$ concentrations where significant $(\mathrm{P}<0.05)$ differences were detected in overall means of plasma $\mathrm{T}_{4}$ $(\mathrm{ng} / \mathrm{mL})$ concentrations between organic-S and control or inorganic groups $(49.87 \pm 5.90$ vs. $29.32 \pm 5.90$ and $29.24 \pm 5.90 \mathrm{ng} / \mathrm{ml}$, respectively). This might indicate increasing basal metabolic rate as a result of trace elements contents of additives. Moreover, providing trace elements was proved to be important for thyroid function. In the same context, serum cortisol concentration was significantly higher in organic-S group compared to other groups. Rising cortisol in late pregnancy stage is of vital importance.

Fowden et al. (1998) explained that umbilical glucose uptake is reduced in fetal ewes during late gestation. When fetal cortisol concentrations are raised, irrespective of whether this increment cortisol is exogenous or endogenous in origin, fetal glucose levels increased despite the reduced umbilical glucose uptake, which suggests that hepatic glycogenesis was activated in these circumstances. Aliarabi et al. (2019) reported that serum $\mathrm{T}_{3}$ concentration was significantly higher in bolus (Zinc, Selenium, and 
Cobalt) given ewes as compared to animals in control group. Where normal thyroid status is dependent on the presence of some trace elements (I, Se, $\mathrm{Zn}$, and $\mathrm{Fe}$ ) for both the synthesis and metabolism of thyroid hormones (Arthur et al., 1999). This result was in agreement with the finding of Abou-Zeina et al. (2009) who reported that zinc supplementation increased total $\mathrm{T}_{3}$. Contrary to our results, Aghwan et al. (2013) who reported that dietary supplementation of iodine and selenium had no effect on free $\mathrm{T}_{4}$ levels $(\mathrm{p}>0.05)$.
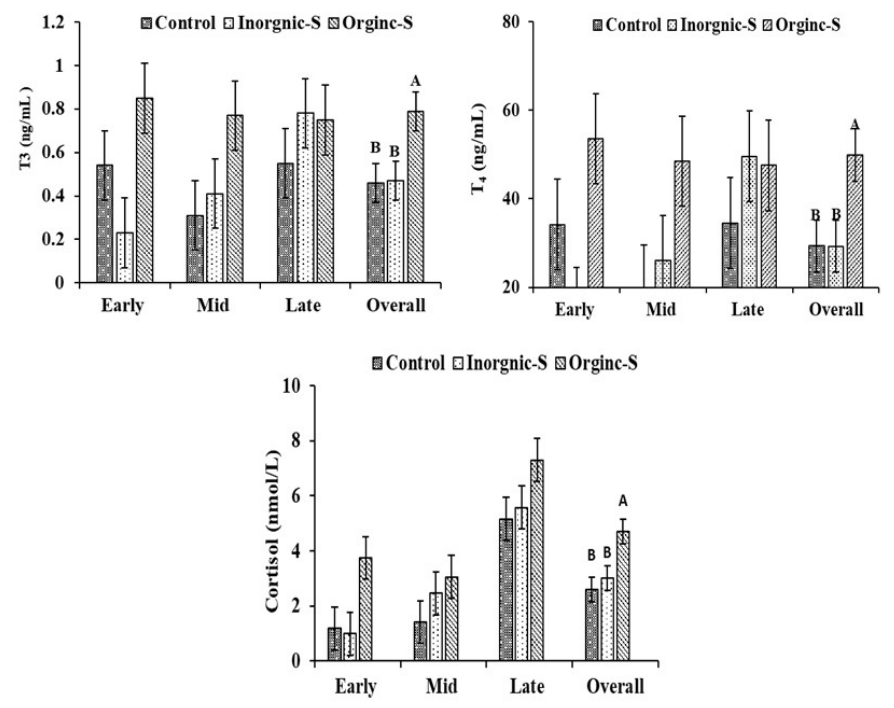

Figure 1: Changes of hormonal profiles in Hassani does fed a basic diet or a diet supplemented with inorganic or organic salts during different pregnancy stages under arid conditions. ${ }^{\mathrm{A}-\mathrm{B}}$ Letters among the group differ significantly $(\mathrm{P}<0.05)$.

\section{IgS CONCENTRATIONS (IGG, IGM) AND IMMUNe} COMPLEMENTS $(\mathrm{C} 3, \mathrm{C} 4)$

The mean of serum $\operatorname{IgG}$ and $\operatorname{IgM}$ concentrations and immune complement $(\mathrm{C} 3, \mathrm{C} 4)$ of the Hassani goats are shown in Figure 2. The serum $\operatorname{IgG}$ concentrations in treated groups increased compared to control group, but treatments did not cause any significant effect on the serum $\mathrm{IgG}$ concentrations. In contrast, the serum IgM concentrations in treated groups increased compared to control group, with high significant differences between organic-S group $(0.36 \pm 0.04 \mathrm{mg} / \mathrm{dL})$, control group $(0.20 \pm 0.04 \mathrm{mg} / \mathrm{dL})$ and inorganic-S group $(0.22 \pm 0.04$ $\mathrm{mg} / \mathrm{dL}$ ). These parameters showed increase values as the pregnancy progresses especially in the organic-S group. These results are consistent with what was mentioned by (Mohamed et al., 2017), where a significant increase in the concentration of $\mathrm{IgG}$ was found in the groups treated with zinc compared to the control. Deficiency in some trace element such as $(\mathrm{Zn}, \mathrm{Fe}, \mathrm{Se}$ and $\mathrm{Ph})$ reduces immune responses and impairs the antioxidant defense system (Chesters, 1997). The higher IgG and IgM concentrations in the blood of goats receiving the different supplemental trace minerals was due to inhibitory effects of $\mathrm{Mn}, \mathrm{Zn}$ and $\mathrm{Cu}$ on oxidative stress and declining the levels of free radicals in the body (Suttle, 2010). Compared to the control group, the significantly higher blood IgM concentration in the organic and inorganic groups trace minerals-supplemented goats as well as the higher blood $\mathrm{IgG}$ concentration in the organic and inorganic trace minerals-fed goats suggested that these minerals probably have important roles in the production of immunoglobulins and supplementing goats with these minerals may improve passive transfer of immunoglobulins in new-born kids. Moreover, in confirmation of the result reported by Zhao et al. (2015), the higher immunoglobulins in the organic minerals-supplemented cows than that in the control group indicated that organic trace minerals may strengthen immunity system in cows.
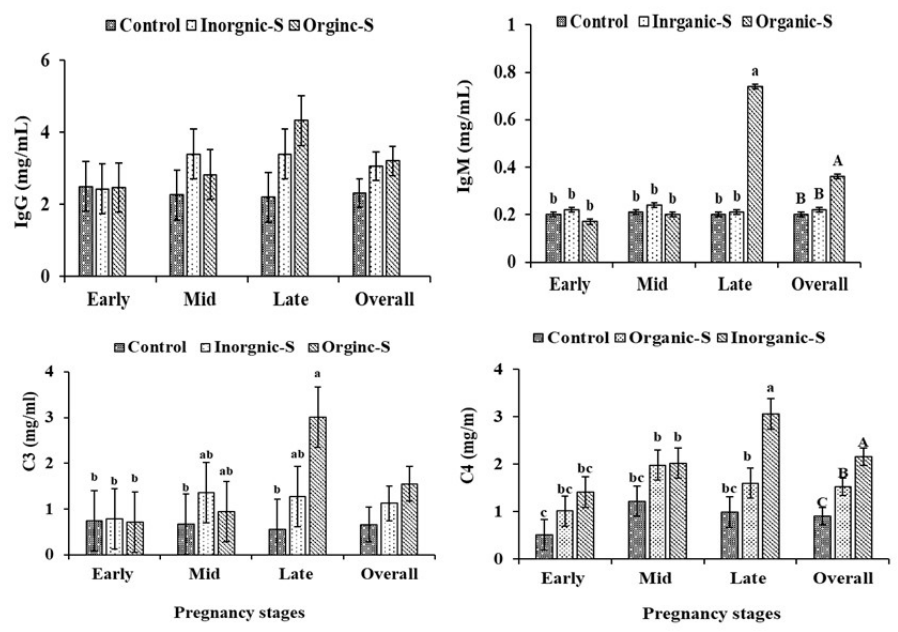

Figure 2: Changes of Changes in plasma ( $\mathrm{IgG}, \mathrm{IgM})$ and immune complement $(\mathrm{C} 3, \mathrm{C} 4)$ in Hassani goats fed a basic diet or a diet supplemented with inorganic or organic salts during different pregnancy stages under arid conditions.

\section{CONCLUSIONS AND RECOMMENDATIONS}

Reproductive performance and immune status in Hassani goats which reared in arid rangelands in Halaieb-Shalateen - Abouramad triangle of Egypt was restored and improved upon trace elements supplementation. Our study results confirmed the importance of the presence of these elements in the diets due to their critical role in reproductive and productive performance of goats. Organic-S minerals supplementation ensured better reproductive efficiency and better performance for the newborn kids.

\section{ACKNOWLEDGMENTS}

Our sincere thanks and gratitude go to Dr. Moustafa M. Ghandour and Dr. Ebrahim Shawky for helpful comments in editing the manuscript. 


\section{AUTHOR'S CONTRIBUTION}

BF helped in carrying out blood analysis in DRC complex laboratories and writing this article. ISA helped analysis of the chemical composition of diets and blood analysis. HAS, MA-HE and FEY helped to collect blood samples and field data during the experiment period. All authors helped in planning the research and statistical analysis of the results. All authors read and approved the final manuscript.

\section{CONFLICT OF INTEREST}

The authors have declared no conflict of interest.

\section{REFERENCES}

-Abd El-Hamid IS, Younis FE, Farrag B, El-Rayes MAH, Shedeed HA (2019). Influence of organic or inorganic forms of salts rich in phosphorus, copper and zinc on reproduction, productivity and blood constituents in sheep. Aust. J. Basic Appl. Sci., 13(6): 14-22.-

-Abdelrahman MM, Aljumaah RS, Khan RU (2017). Effects of prepartum sustained-release trace elements ruminal bolus on performance, colostrum composition and blood metabolites in Najdi ewes. Environ. Sci. Pollut. Res., pp. 9675-9680. https://doi.org/10.1007/s11356-017-8625-1

-Abou-Zeina H, Hassan S, Sabra H, Hamam A (2009). Trials for elevating adverse effect of heat stress in buffaloes with emphasis on metabolic status and fertility. Glob. Vet., 3(1): 51-62.

-Abraham GE (1974). Ovarian and adrenal contribution to peripheral androgens during the menstrual cycle. J. Clin. Endocrinol. Metab., 39: 340-346. https://doi.org/10.1210/ jcem-39-2-340

-Aghwan ZA, Sazili AQ, Alimon AR, Goh YM Hilmi M (2013). Blood hematology, serum thyroid hormones and glutathione peroxidase status in Kacang goats fed inorganic iodine and selenium supplemented diets. Asian-Australian J. Anim. Sci., 26: 1577-1582. https://doi.org/10.5713/ ajas.2013.13180

-Ahola JK, Baker DS, Burns PD, Mortimer RG, Enns RM, Whittier JC, Geary TW, Engle, TE (2004). Effect of copper, zinc and manganese supplementation and source on reproduction, mineral status and performance in grazing beef cattle over a two-year period. J. Anim. Sci., 82: 23752383. https://doi.org/10.2527/2004.8282375x

- Aliarabi H, Fadayifar A, Alimohamady R, Dezfoulian AH (2019). The effect of maternal supplementation of zinc, selenium, and cobalt as slow-release ruminal bolus in late pregnancy on some blood metabolites and performance of ewes and their lambs. Biol. Trace Elem. Res., 187(2): 403410. https://doi.org/10.1007/s12011-018-1409-8

-Antunovic Z, Novoselec J, Sauerwein H, Speranda M, Vegara M, Pavic V (2011). Blood metaboliv profile and some of hormones concentration in ewes during different physiological status. Bulg. J. Agric. Sci., 17: 687-695.

-Antunovic Z, Sencic D, Sperada M, Liker B (2002). Influence of the season and the reproductive status of ewes on blood parameters. Small Rumin Res., 13: 147-151.

-Arthur JR, Beckett GJ, Mitchell JH (1999). The interactions between selenium and iodine deficiencies in man and animals. Nutr. Res. Rev., 12(01): 55-73. https://doi. org/10.1079/095442299108728910

- Badawy HSM (2005). Nutritional studies on camels grazing the natural ranges of Halaib- Shalateen triangle region $\mathrm{Ph} . \mathrm{D}$. thesis, Fac. Agric., Cairo Univ. Egypt. pp. 215.

- Badawy NS, Abdou AS, El-Rayes MAH (2018). Studies on the effect of some salt additives on the skin and coat characteristics of sheep in Hederba valley ranges. Egypt. J. Nutr. Feeds, 21: 81-92. https://doi.org/10.21608/ ejnf.2018.75410

-Bauer JD (1970). Numerical evaluation of red blood cells, white blood cells and platelets. Part III. Hematology in Grandwell Clinical Laboratory Methods and Diagnosis. (Ed. S. Frankel.).

-Boland TM, Keane N, Nowakowski P, Brophy PO, Crosby TF (2005). High mineral and vitamin $\mathrm{E}$ intake by pregnant ewes lowers colostral immunoglobulin $G$ absorption by the lamb. J. Anim. Sci., 83(4): 871-878. https://doi. org/10.2527/2005.834871x

- Cheesbrough M (2010). District laboratory practice in tropical countries in laboratory manual, UK, Cambridge Univ. Press, pp. 146-157.

- Cheryl A, Lotspeich-Steininger E, Anne Stiene-Martin John KA (1992). Clinical hematology: Principles, procedures, correlations. Philadelphia: Lippincott, 1992.

- Chesters JK (1997). Zinc. In: Handbook of Nutritionally Essential Mineral Elements, [BL O'Delland RA Sunde, editors]. New York: Marcel Dekker Inc. pp. 185-230.

- Cook NB, Bennett TB, Emery KM, Nordlund KV (2002). Monitoring nonlactating cow intramammary infection dynamics using DHI somatic cell count data. J. Dairy Sci., 85: 1119-1126. https://doi.org/10.3168/jds.S00220302(02)74173-8

- Cristaldi LA,McDowel LR, Buergelt, CD, Davis PA, Wilkinson NS Martin FG (2005). Tolerance of inorganic selenium in wether sheep. Small Rumin. Res., 56: 205-213. https://doi. org/10.1016/j.smallrumres.2004.06.001

-El-Rayes MAH (2019). Studying the effect of adding some mineral salts on physiological and productive performance of grazing Darashawy ewes during late pregnancy in Hadraba valley, south. Eur. J. Biomed. Pharma. Sci., 6(13): 28-49.

-El-Shaer HM, Kandil HM, Abou El-Nasr H, Khamis HS (1997). Features and constrains of animal resources development in Shalateen- Halaieb region. Egypt. J. Nutr. Feeds (Special Issue), pp. 121-128.

- Formigoni A, Fustini M, Archetti L, Emanuele S, Sniffen C, Biagi G (2011). Effects of an organic source of copper, manganese and zinc on dairy cattle productive performance, health status and fertility. Anim. Feed Sci. Tech., 164: 191198. https://doi.org/10.1016/j.anifeedsci.2011.01.010

- Fowden AL, Li J, Forhead AJ (1998). Glucocorticoids and the preparation for life after birth are there long term consequences of the life insurance? Proc. Nutr. Soc., 57: 113-122. https://doi.org/10.1079/PNS19980017

- Garg AK, Mudgal V, Dass RS (2008). Effect of organic zinc supplementation on growth, nutrient utilization and mineral profile in lambs. Anim. Feed Sci. Tech., 144: 82-96. https:// doi.org/10.1016/j.anifeedsci.2007.10.003

- Kinal S, Korniewicz A, Słupczyńska M, Bodarski R, Korniewicz D, Čermak B (2007). Effect of the application of bioplexes of zinc, copper and manganese on milk quality and composition of milk and colostrum and some indices of the 
blood metabolic profile of cows. Czech J. Anim. Sci. Agric. J., 52: 423-429. https://doi.org/10.17221/2338-CJAS

- Kumar S (2003). Management of infertility due to mineral deficiency in dairy animals. In proceedings of ICAR summer school on "Advance diagnostic techniques and therapeutic approaches to metabolic and deficiency diseases.

- Kumar N, Garg AK, Dass RS, Chaturvedi VK, Varshney VP (2009). Effect of dietary supplementation of inorganic and organic selenium on intake and utilization of nutrients. Anim. Nutr. Feed Techn., 9: 253-260.

-Lengarite MI, Mbugua PN, Gachuiri CK, Kabuage LW (2012). Mineral status of sheep and goats grazing in the arid rangelands of Northern Kenya. Pak. J. Nutr., 11(4): 383-390. https://doi.org/10.3923/pjn.2012.383.390

-McDowell LR, Conrad JH, Hembry FG (1993). Minerals for grazing ruminants in tropical regions. Univ. Florida, Gainesville.

-McDowell LR, Valle G (2000). Major minerals in forages. Forage evaluation in ruminant nutrition (Ed. D. I. Givens, E. Owen, R.F.E. Oxford and H.M. Omed). CAB Int., Wallingford, UK. pp. 373. https://doi.org/10.1079/9780851993447.0373

- Mohamed AH, Mohamed MY, Ibrahim K, Fatma Abd ElGhany TF, Mahgoup AAS (2017). Impact of nano-zinc oxide supplementation on productive performance and some biochemical parameters of ewes and offspring. Egypt.J. Sheep Goat Sci., 12(3): 49-64. https://doi.org/10.12816/0044928

-Mutinati M, Piccinno M, Roncetti M, Campanile D, Rizzo A, Sciorsci RL (2013). Oxidative stress during pregnancy in the sheep. Review article. Reprod. Domest. Anim., 48: 353-357. https://doi.org/10.1111/rda.12141

- Nassar MSM (2008). Nutritional aspects and supplementary feeding for local goats on ranges of halaib and shalaten region. Ph.D. thesis. Dep. Anim. Prod. Fac. Agric. Cairo Univ. Egypt.

- Norouzian MA, Malaki M, Khadem AA (2014). Effects of parenteral administration of cobalt, copper and iron in late pregnancy on ewe hematology and lamb vigour. Iran.J. Appl. Anim. Sci., 4(2): 285-289.

- Overton TR, Yasui T (2014). Practical applications of trace minerals for dairy cattle. J. Anim. Sci., 92: 416-426. https:// doi.org/10.2527/jas.2013-7145

-Pechova A, Pavlata L, Dvorak R, Lokajova E (2009). The concentrations of $\mathrm{Zn}, \mathrm{Cu}, \mathrm{Mn}$ and $\mathrm{Se}$ in milk in relation to the concentration of microelements in blood, daily milk and stage of lactation in dairy cattle. Acta Vet. Brno., 77: 523-531. https://doi.org/10.2754/avb200877040523

-Sallam M, Ramadan S, Helal M, Mahbou H (2017). Effects of organic minerals mixture supplementation on performance and immune status of goats and their kids. Int. J. Biol. Sci. Appl., 4(4): 32-37.

-SAS Institute Inc (2006). Base SAS 9.1.3 procedures guide, Second Edition. SAS Institute Inc., Cary, NC.

- Schalm OW,Jain NC Carrol EJ (1975). Veterinary Haematology, $3^{\text {rd }}$ Edn., Lea and Febiger, Philadelphia, pp. 197-199.

- Senosy W, Kassab AY, Hamdon HA, Mohammed AA (2018). Influence of organic phosphorus on reproductive performance and metabolic profiles of anoestrous Farafra ewes in subtropics at the end of breeding season. Reprod. Domest. Anim., 53: 904-913. https://doi.org/10.1111/ rda. 13183

- Silanikove N (2000). Effects of heat stress on the welfare of extensively managed domestic ruminants. Livest. Prod. Sci., 67: 1-18. https://doi.org/10.1016/S0301-6226(00)00162-7

- Suttle NF (2010). The mineral nutrition of livestock. $4^{\text {rd }}$ ed. New York, NY: CABI; 2010. https://doi. org/10.1079/9781845934729.0000

- Swenson CK (1998). Influence of mineral supplementation on blood serum and liver mineral concentrations in first calf beef heifers. Ph. D. Dissertation. NM State Univ., Las Cruces.

- Tayefi-Nasrabadi H, Moghaddam GH, Rajabi Z (2008). Effect of zinc ion on peroxidase activity of serum in cow. Pak. J. Biol. Sci., 11: 2589-2593. https://doi.org/10.3923/ pjbs.2008.2589.2593

-Underwood EJ, Suttle NF (1999). The mineral nutrition of livestock, $3^{\text {rd }}$ edn. CAB Int., Wallingford, UK.

- Underwood EJ, Suttle NF (2001). The mineral nutrition of livestock. $3^{\text {rd }}$ ed. London: CABI Publishing, Biddles Ltd.

- Van Metre DC, Callan RJ (2001). Selenium and vitamin E. In: VanMetre DC (ed) Update on small ruminant medicine. Vet. Clin. North Am. Food Anim. Pract., W.B. Saunders, Philadelphia. 17(2). https://doi.org/10.1016/S07490720(15)30034-7

-Zhao XJ, Li ZP, Wang JH, Xing XM, Wang ZY, Wang L (2015). Effects of chelated $\mathrm{Zn} / \mathrm{Cu} / \mathrm{Mn}$ on redox status, immune responses and hoof health in lactating Holstein cows. J. Vet. Sci., 16(4): 439e46. https://doi.org/10.4142/ jvs.2015.16.4.439 